\title{
An Empirical Investigation of the Mentor-Mentee Relationship Among Female Architects and Female Architectural Students
}

\author{
https://doi.org/10.3991/ijet.v16i13.21971 \\ Adedeji Olushola Afolabi ${ }^{(凶)}$, Adedotun Akinola \\ Covenant University, Ota, Nigeria \\ adedeji.afolabi@covenantuniversity.edu.ng
}

\begin{abstract}
Women are highly underrepresented in the construction industry. In line with the sustainable development goals (SDGs) of the United Nations of gender quality and reducing inequalities, there is a need to think of innovative and sustainable frameworks to increase women's quota in the construction trade, especially in architecture. The study investigated the mentor-mentee relationship between female Architects and female Architectural students.

The study utilized a research survey approach using a questionnaire data instrument. Using a purposive sampling technique, 84 research participants, consisting of female Architects and female Architecture students, participated in this study. The data collected are presented using bar charts, mean scores, principal component analysis (PCA), and categorical regression (CAT-REG).

The study identified characteristics associated with good Mentors and good Mentees in the design profession. Mentees identified the main features that make a good mentor as the ability to teach, listen attentively, and communicate effectively. On the other hand, Mentors identified the qualities of a good mentee who communicates, is focused and demonstrates intelligence. The study showed that the significant negative experiences in a mentor-mentee relationship include a clash of personalities between the mentors and mentees, stealing credit for work done by both parties, and unrealistic expectations. Furthermore, these negative experiences result from poor attitude, wrong emotions, and loss of motivation.

In conclusion, the study showed that proper implementation of Women mentoring programs among design professionals could lead to potential outcomes such as improved productivity, empowerment of inexperienced personnel, attracting likely female students, retaining women professionals, higher salaries, higher job satisfaction, and an increase in role models/mentors
\end{abstract}

Keywords - Construction Industry, Design Industry, Mentee, Mentor, Women

\section{Introduction}

The construction environment is mainly complex due to the interaction between the buildings being constructed and the different construction professionals' genres. Apart 
from the unskilled and skilled artisans used on construction sites, other notable construction professionals such as Architects, Builders, Service Engineers, and Quantity Surveyors participate in successfully delivering buildings [1]. To sustain the adequate supply of these occupations, suggestions have been hinged on increasing women's quota in the construction profession. Increasing women's participation in the construction industry has been linked to the innovative measures of mentoring in previous studies [2, 3, 4]. From these studies, the understanding that mentoring brings to the fore is the ability to teach, knowledge transfer, and influence others. By applying this to the construction industry, women should encourage and guide other women into their respective chosen professions within the industry. Mentors should be able to take mentees on the career paths the Mentor has taken and other opportunities available in the construction industry. This becomes an important instrument that aids not just in attracting women to the profession but ensuring that they grow through different cadres within the industry. This is evident in the study by [5], where mentoring is regarded as a supportive relationship. It is important to note that individuals should not confuse mentoring in the construction industry as the same in other sectors within the economy. This is due to the dynamic nature and complexity associated with the construction industry's activities [6].

[7] showed a continuous need to continually ask the question: why are there few women in the construction industry? Or is it that they do not have the required skills and competencies to thrive within the industry? The answers proffered in [8] and [9] are mainly that women's competencies needed for the construction industry are primarily suppressed due to the construction industry's anti-feminine characteristics. This is not far-fetched in that women face a lot of challenges in the construction industry. These challenges have been attributed to the image the industry portrays, male-dominance, low working environment, undue pressure, and so on $[8,9]$. The image of the Nigerian construction industry significantly discriminates against the contributions of women to the sector. While the working condition is not femalegender friendly, some women construction professionals thrive in the industry. [10] opined that the low image attributed to the industry has been continuously fueled by the general lack of knowledge and limited insight into the potential career opportunities by prospective new entrants in the construction sector. This insufficient knowledge and information among less experienced female students/workers interested in building and construction activities could be readily influenced through effective women mentoring. Despite these challenges in the construction industry, there are many socio-economic benefits associated with women's active participation in the industry.

This study makes a crucial case for design professionals, especially for the architectural profession, due to their pivotal role in the construction industry. This study, like similar studies in [11], [12], and [13], believes that it would be a monumental waste for students to put in for architecture due to their passion for the profession and end up not practicing due to sinister tales they have been misinformed about the industry. Furthermore, the students should not just be attracted to the job. Still, they should also be able to advance in the profession due to the availability of the right information and support from experienced Architects. Beyond the design and 
construction industry, the learning outcomes of the students is also paramount. Previous studies that have considered the learning outcomes of students can be found in [14], [15], and [16]. Therefore, proffering mentoring as a strategic solution to increasing female architects in the design profession, the study asked the following research questions;

- What are the main characteristics expected in a good mentor/mentee in a women mentor-mentee relationship?

- What are the negative experiences that may arise from an ineffective mentormentee relationship?

- Which potential outcomes are paramount in an effective woman mentoring program among design professionals?

\section{Review of Related Literature}

One crucial attribute of mentoring is the level and type of information the Mentor possesses. With this information, the Mentor can support a junior colleague usually referred to as the mentee in the mentor-mentee relationship. This attribute becomes vital for the construction industry in that the industry thrives and functions on information. This information becomes critical for new entrants for their sustenance and growth in this sector. The dimension of innovation put forward in this study is that the design profession and design education can adequately benefit from an effective mentor-mentee relationship between female Architects and female architectural students. Apart from the mentee gaining in the mentoring process, other aspects of the construction industry gain. This study posits that knowledge is generated in the mentor-mentee relationship cycle, which is beneficial to the firm and further research into an effective mentoring program for the construction industry.

In the study by [17], they stated that mentoring should be guided by certain principles that ensure that a mentee's goal is empowered through constant engagement between the Mentor and mentee. Apart from new entrants and students, mentoring has been used by some firms on some under-performing workers to increase their productivity in the workplace [3]. Furthermore, the benefits of mentoring can be witnessed in the increase in pay of the mentee in their workplace [18], better satisfaction and improved self-respect from the worker being mentored [19], the mentee being more committed to the firm [20], and other psychosocial benefits [18, 19]. Specifically, [21] showed that women could benefit in terms of career development in the Australian construction industry due to an effective mentoring/role model program. Similar results were concluded in New Zealand's construction industry due to the vast mentoring opportunities that helped create women networks. In the United Kingdom, mentoring programs among women have achieved better work-life balance in the workplace, better placement for women according to their skills and talents [9]. Through the process of mentoring, [17] argued that the Mentor's role becomes one that helps the mentee discover potentials within the individual that can help increase productivity. Despite the theoretical knowledge garnered by the mentee during their undergraduate studies at their higher institutions, 
mentors should help mentees translate this into applicable principles at the workplace. $[22,23]$.

Choosing the right Mentor is very crucial for an effective mentoring program. This study posits that not everyone can become a mentor because specific characteristics must be possessed to become one. To be an effective mentor or mentee in the construction industry, one must identify the features that would help the mentoring process and cycle become a success [24]. A mentee may approach a mentor for support in their career goals due to the Mentor's experience. Still, other characteristics of the Mentor would determine if the mentoring experience is sustained or becomes frustrating. This applies to the mentee as well, in that the Mentor looks forward to certain good qualities in the mentee that encourages and motivates a stimulating mentoring atmosphere [25]. One of the first characteristics that the Mentor must possess is listening to ability. The Mentor should listen to the mentee without any form of assumptions in the mentoring process [26]. Other characteristics of a good mentor identified in the study by [27] include an outstanding superior, good interpersonal relationship qualities, ability to identify and encourage each other's milestones, and understanding of the risks and challenges accompanying the mentoring process. In the mentoring process, both the Mentor and mentee should outline achievable goals, be flexible, and ensure no form of discord or disagreement leading to an unharmonious mentor-mentee relationship [25]. The Mentor and mentee should ensure that the objectives of the mentoring relationship are the main focus. This mindset must resonate throughout the mentoring cycle. Due to the mentee's lack of experience, the Mentor needs to provide support through the push and pull effect [28]. By this, the Mentor makes the mentee understand his or her strengths and limitations [25]. For both parties, [27] noted that there must be a process that shows availability in the mentoring process. Specifically, there are unique characteristics in the construction industry that would make a mentor thrive in a mentor-mentee relationship. These characteristics were identified in [24] as ability to share and communicate knowledge, correct the mentee, and give constructive criticism. When these good characteristics are missing in either party, the mentoring process's success becomes questionable and may strain both parties [29].

To be an effective mentee, mentors look forward to mentees who show high commitment to being empowered to achieve their career goals [27]. This study posits that understanding each other's characteristics is crucial and a two-way system. The mentee should have some form of intelligence needed in the chosen career and willing to take responsibility for their career growth. Emphatically, this study points out that some characteristics need to be taught to prospective mentees through a practical mentoring workshop. For example, apparent in one's goals may not come instinctively or goals setting skills. However, these skills can be taught and understood by prospective mentees before venturing into a mentoring cycle. In the study by [25], they opined that mentees need to be punctual to set meetings, be opened to Mentor's contribution, be discreet, understand their roles as a mentee, and set boundaries in the mentor-mentee relationship. 


\section{$3 \quad$ Research Methods}

The study focuses on the increase in participation of women among design professionals through an effective women mentor-mentee relationship. This inclusive workplace area amongst the female gender proffers the solution of using women mentoring by female leaders in the construction industry and among design professionals. As pointed out by [4], the onus is on women to encourage the younger female students to take up a career in the construction field after their undergraduate program. This work is based on an earlier literature-based work in [30] as a note of transparency. In [30], the theoretical background of this article was laid. Since this study is judgmental research focused on the research participants' perception, a survey research design was used. The cross-sectional survey research design utilized a wellstructured questionnaire instrument to obtain answers to the identified research questions. The study was carried out within Nigeria, specifically in Lagos and Ogun State. These locations were selected due to the high quota of research participants within this study area.

The study focused on design professionals: the study utilized female Architects and female Architectural students within the study area. There is no definitive list of female Architects and female Architectural students; therefore, a purposive sampling technique was used in selecting the sample size for this study. This presented the mentor-mentee relationship under investigation in this study: the chosen study architects and architectural students due to their importance in the construction industry. Architects form the first form of contact with clients in the construction industry. Architects use their designs to create balance and improve productivity within spaces. However, past studies have shown the decline in female Architects and female Architectural students who end up practicing the profession [31, 32, 33].

A total of 100 questionnaire instruments were distributed to each segment of research participants. There were two sets of questionnaire instrument designed for this study. Each questionnaire instrument had four sections of the participants' information, excellent mentor/mentee characteristics, negative experiences in women mentor-mentee relationship, and potential outcomes to effective women mentoring program among design professionals. However, only a $42 \%$ data retrieval rate was recorded in the data collection within the space of three months (January - March 2019) of data gathering. The study ensured equal participation between the two groups, with 42 persons representing each group within the study area. The data collected are presented using bar charts, mean scores, principal component analysis (PCA), and categorical regression (CAT-REG).

\section{$4 \quad$ Result and Discussion of Findings}

This section presented the data analysis of the research questions and the discussion of findings related to women mentor-mentee relationships among female Architects and female Architectural students. The study utilized two segments of research participants, i.e., female architects and female architectural students. Figure I 
shows the summarized bar chart presentation of the women architects' highest academic qualification, industry work experience, and work sector. In Figure 1, 28 $(66.7 \%)$ of the female architects had a Masters's degree, while $11(26.2 \%)$ had a Doctoral degree in architecture. The industry work experience distribution shows that $23(54.8 \%)$ of the female architects had $11-20$ years' work experience. However, the female architects were in different sectors in the Nigerian economy. Figure 1 shows that $20(47.6 \%)$ of the female architects work in the consulting industry, $11(26.2 \%)$ work in the contracting sector, $3(7.1 \%)$ work for the government, and $7(16.7 \%)$ work in the education sector. In all, the female architects were practicing architects and had adequate knowledge within this study's frame. It was essential to highlight the characteristics of the female architectural students. The female students were selected at the postgraduate and undergraduate levels within a private tertiary institution.

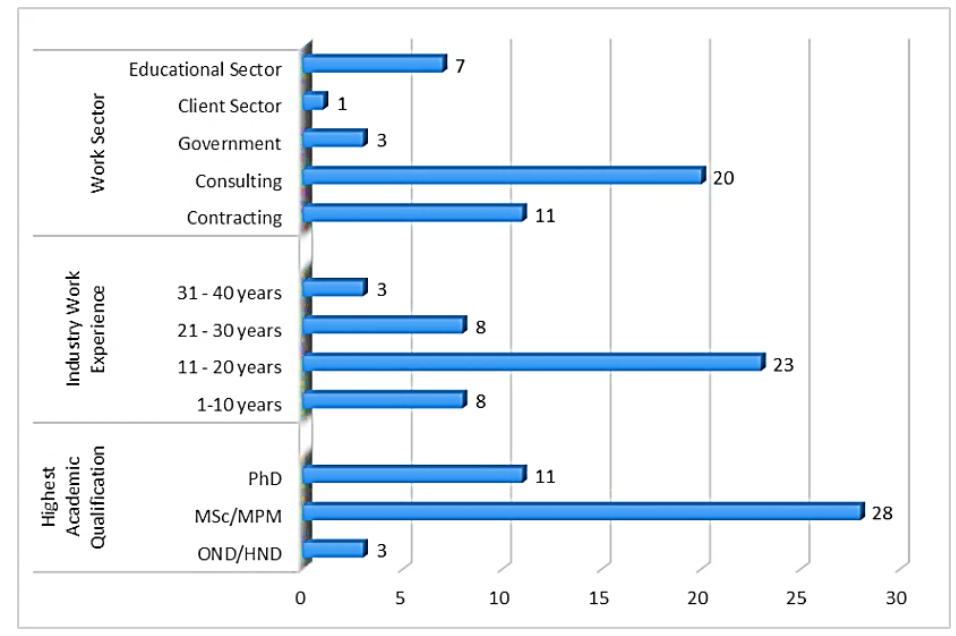

Fig. 1. Summarized background information of Female architects'

Figure 2 shows the summarized bar chart of the female architects' age distribution, mentorship status, and plans to practice architecture among the students. In Figure 2, the female architecture students' age distribution shows that it is a fair distribution. Most of the female architecture students were between 20 to 23 years. The students were further questioned on if they had a mentor. Figure 2 shows that $25(59.5 \%)$ do not have mentors in the architectural profession, while 17 (40.5\%) had active mentors. Since the study is concerned about attracting and retaining Architectural students in the design profession, the study sought to determine if the students planned to practice after graduation. The study showed an equal distribution in the plan to practice architecture after graduation among the female students. 


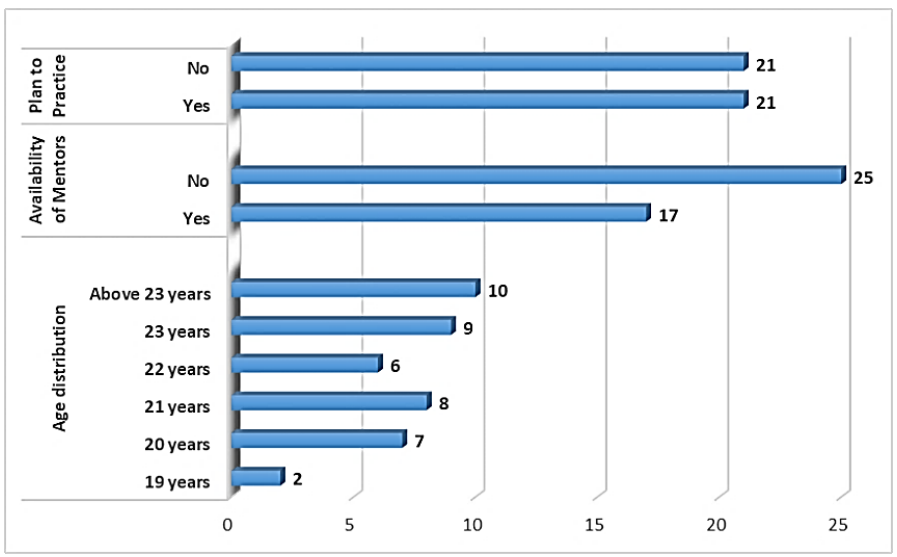

Fig. 2. Summarized background information of female architectural students

The findings in this study are insightful as it shows there is still a need to encourage Architectural students to practice. Further Analysis using cross-tabulation showed in Table 1 shows the cross tabulation between mentorship status among the female architecture students and their plan to practice. Table 1 indicates that there are higher chances for those that have mentors to proceed to practice architecture.

Table 1. Cross Tabulation of Status of Mentorship and Plan to Practice

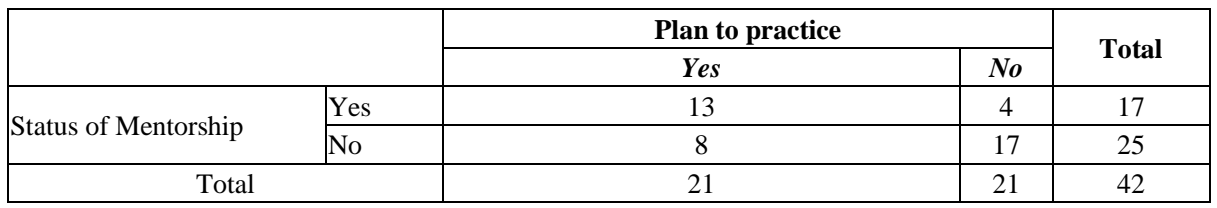

\subsection{Characteristics of good mentors/mentees}

For a successful mentoring relationship, both the Mentor and mentee must bring specific skills and characteristics to the table. The study highlighted the essential qualities of good mentors/mentees in a women mentoring relationship. This perception study showed each research participants' affinity towards each mentor/mentee characteristics needed to foster an effective mentor-mentee relationship. Good mentors/mentees' characteristics in a women mentoring relationship were identified from previous studies [25] and [34]. [25] noted that any mentoring relationship's success is mostly hinged on the characteristics possessed by either the Mentor or mentee before the association being formed. As identified in this study, a mentor's characteristics look forward to a potential mentee differ from the qualities that a mentee looks forward to in a potential mentor. Table 2 and 3 show the feature of good mentors/mentees in a women mentoring relationship. In Table 2, the main characteristics identified as qualities of a good mentor are teaching, listening attentively, and communicating effectively. This is supported by $[24,26]$, in that a 
mentor that listens attentively and communicates effectively helps create a safe environment for the mentor-assisted relationship to flourish. This characteristic ensures that the Mentor is not biased or pass unfair judgment on the mentee and help agree on specific objectives and goals. The study by [25] also agrees with these findings. Their review stated that listening and asking the mentee's right questions are essential characteristics that a good mentor must possess. [25] opined that these characteristics would help build and maintain a harmonious relationship through trust, empowerment, focus, and empathy.

Table 2. Characteristic of good mentors in a women mentoring relationship

\begin{tabular}{|c|c|c|c|c|}
\hline Characteristics & MS & SD & $\mathbf{R I}$ & Remark \\
\hline Ability to teach & 4.81 & 0.397 & $1^{\text {st }}$ & Very Important \\
\hline Listens attentively & 4.71 & 0.554 & $2^{\text {nd }}$ & Very Important \\
\hline Communicates effectively & 4.69 & 0.468 & $3^{\text {rd }}$ & Very Important \\
\hline Flexible and open to suggestions & 4.57 & 0.668 & $4^{\text {th }}$ & Very Important \\
\hline Excellent leadership qualities & 4.57 & 0.590 & $4^{\text {th }}$ & Very Important \\
\hline Supportive & 4.57 & 0.630 & $4^{\text {th }}$ & Very Important \\
\hline Quality years of construction experience & 4.55 & 0.670 & $7^{\text {th }}$ & Very Important \\
\hline Excellent Supervisor & 4.52 & 0.707 & $8^{\text {th }}$ & Very Important \\
\hline Approachable & 4.52 & 0.707 & $8^{\text {th }}$ & Very Important \\
\hline Resourceful & 4.50 & 0.595 & $10^{\text {th }}$ & Very Important \\
\hline Confident & 4.50 & 0.595 & $10^{\text {th }}$ & Very Important \\
\hline Patient & 4.50 & 0.634 & $10^{\text {th }}$ & Very Important \\
\hline Creates a safe environment for mentoring & 4.48 & 0.594 & $13^{\text {th }}$ & Important \\
\hline Honest & 4.48 & 0.707 & $13^{\text {th }}$ & Important \\
\hline Recognizes achievement of the mentee & 4.43 & 0.737 & $15^{\text {th }}$ & Important \\
\hline Role Model & 4.43 & 0.703 & $15^{\text {th }}$ & Important \\
\hline Enjoys her work & 4.43 & 0.703 & $15^{\text {th }}$ & Important \\
\hline Gives positive and negative feedback & 4.40 & 0.544 & $18^{\text {th }}$ & Important \\
\hline Manages conflict effectively & 4.38 & 0.661 & $19^{\text {th }}$ & Important \\
\hline Strong interpersonal attributes & 4.38 & 0.764 & $19^{\text {th }}$ & Important \\
\hline $\begin{array}{l}\text { Accepts risk and uncertainties of } \\
\text { mentoring }\end{array}$ & 4.31 & 0.811 & $21^{\mathrm{st}}$ & Important \\
\hline Allows mentee to make mistakes & 4.29 & 0.805 & $22^{\text {nd }}$ & Important \\
\hline Emotional Intelligence & 4.29 & 0.774 & 23rd & Important \\
\hline Empathy & 4.12 & 0.916 & $24^{\text {th }}$ & Important \\
\hline
\end{tabular}

* MS = Mean Score SD = Standard Deviation; RI = Ranking Index

[34] argued that the success of a mentoring relationship is hinged on the good character of the Mentor and hinged on the sound characteristics possessed by the mentee. Table 3 shows the part of good mentees in a women mentoring relationship. Table 3 presents the main features essential for an excellent mentee to communicate, focused, and demonstrate intelligence. [27] corroborated the findings in this study. Mentors associate better with mentees who can demonstrate high level of intelligence, take the initiative, and be responsible for their development. Besides, [25] pointed out the importance of a mentee that can communicate clearly. Mentees in a mentorassisted relationship should be able to express their needs clearly and developmental 
goals. Table 2 and 3 show that one of the essential qualities in a mentor-mentee relationship in women mentoring is communication among the persons involved.

Table 3. Characteristic of good mentees in a women mentoring relationship

\begin{tabular}{|l|c|c|c|l|}
\hline \multicolumn{1}{|c|}{ Characteristics } & MS & SD & RI & \multicolumn{1}{|c|}{ Remark } \\
\hline Communicates clearly & 4.52 & 0.594 & $1^{\text {st }}$ & Very Important \\
\hline Focused & 4.52 & 0.594 & $1^{\text {st }}$ & Very Important \\
\hline Demonstrates Intelligence & 4.38 & 0.697 & $3^{\text {rd }}$ & Important \\
\hline Understand boundaries & 4.38 & 0.697 & $3^{\text {rd }}$ & Important \\
\hline Uses feedback for positive output & 4.31 & 0.563 & $5^{\text {th }}$ & Important \\
\hline Positive attitude & 4.31 & 0.680 & $5^{\text {th }}$ & Important \\
\hline Takes initiatives & 4.31 & 0.680 & $5^{\text {th }}$ & Important \\
\hline Open to constructive criticism & 4.24 & 0.656 & $8^{\text {th }}$ & Important \\
\hline Strong interpersonal attributes & 4.17 & 0.621 & $9^{\text {th }}$ & Important \\
\hline Timely response to goals & 4.17 & 0.730 & $9^{\text {th }}$ & Important \\
\hline Maintains confidentiality & 4.17 & 0.730 & $9^{\text {th }}$ & Important \\
\hline Punctuality at mentor meetings & 4.17 & 0.908 & $9^{\text {th }}$ & Important \\
\hline Takes Responsibilities for own development & 4.17 & 0.621 & $9^{\text {th }}$ & Important \\
\hline Reliable and Persistent & 4.10 & 0.790 & $14^{\text {th }}$ & Important \\
\hline Flexible and adaptable & 3.95 & 0.697 & $15^{\text {th }}$ & Neutral \\
\hline Understand the roles of each party & 3.88 & 0.739 & $16^{\text {th }}$ & Neutral \\
\hline Seeks input from the Mentor & 3.81 & 0.943 & $17^{\text {th }}$ & Neutral \\
\hline Manages conflict appropriately & 3.74 & 0.798 & $18^{\text {th }}$ & Neutral \\
\hline
\end{tabular}

$* \mathrm{MS}=$ Mean Score $\mathrm{SD}=$ Standard Deviation; RI = Ranking Index

\subsection{Negative mentoring experiences in a mentor-mentee relationship}

This section highlighted negative mentoring experiences that may arise as a result of an ineffective women mentor-mentee relationship. Table 4 shows the mean score of negative experiences among mentors and mentees, measured using a 5-point Likert scale. The cross-tabulation across the group participants indicated that the mentees had encountered negative mentoring experiences such as unrealistic expectations from mentors, issues relating with pride from mentors, mentors bringing personal problems into the mentor-mentee relationship, and loss of interest in the profession. On the other hand, mentors have encountered negative experiences such as overdependence from mentees, clash of personalities, and too much workload on one party. The overall significant negative experiences that have been discovered among mentees and mentors in a mentor-mentee relationship include a clash of personalities between the mentors and mentees, stealing of credit for work done by both parties, and unrealistic expectations. [3] The construction industry is a sector filled with tight deadlines leading to tension and anxiety on construction professionals. The way each person deals with these construction environment stressors differs and can lead to clashes in a mentor-mentee relationship if not handled well. [2] stated that this conflict in personalities between mentors and mentees could lead to arguments and personal problems that can affect work productivity. On the other hand, what interests a mentor may not involve the mentee. With this uniqueness, there are bound to be 
personality differences. Therefore, there is a need to learn to manage them and deal with these differences in a constructive manner.

Table 4. Negative mentoring experiences in a mentor-mentee relationship

\begin{tabular}{|c|c|c|c|c|c|}
\hline \multirow{2}{*}{ Negative Experiences } & Mentee & Mentor & \multirow{2}{*}{$\begin{array}{c}\text { Overall } \\
* \mathrm{MS}\end{array}$} & \multirow{2}{*}{$\mathbf{R I}$} & \multirow{2}{*}{ Remark } \\
\hline & $* M S$ & $* M S$ & & & \\
\hline Clash of personalities & 3.79 & 3.29 & 3.54 & $1^{\text {st }}$ & Moderate \\
\hline Stealing of credit for work done by both parties & 3.93 & 3.02 & 3.48 & $2^{\text {nd }}$ & Moderate \\
\hline Unrealistic expectations & 4.05 & 2.84 & 3.45 & $3^{\text {rd }}$ & Moderate \\
\hline Argument and conflict & 3.86 & 3.02 & 3.44 & $4^{\text {th }}$ & Moderate \\
\hline Too much workload on one party & 3.79 & 3.10 & 3.44 & $4^{\text {th }}$ & Moderate \\
\hline Bringing personal problems into the relationship & 4.00 & 2.88 & 3.44 & $4^{\text {th }}$ & Moderate \\
\hline Overdependence & 3.52 & 3.33 & 3.43 & $7^{\text {th }}$ & Moderate \\
\hline Loss of interest in the profession & 4.00 & 2.86 & 3.43 & $7^{\text {th }}$ & Moderate \\
\hline Bad attitude & 3.76 & 2.90 & 3.33 & $9^{\text {th }}$ & Moderate \\
\hline Pride & 4.02 & 2.48 & 3.25 & $10^{\text {th }}$ & Moderate \\
\hline Inappropriate delegation of duties & 3.57 & 2.83 & 3.20 & $11^{\text {th }}$ & Moderate \\
\hline Allowing third-party negative influence & 3.69 & 2.57 & 3.13 & $12^{\text {th }}$ & Moderate \\
\hline Sabotage & 3.67 & 2.50 & 3.08 & $13^{\text {th }}$ & Moderate \\
\hline Inadequate time for the relationship & 3.14 & 2.98 & 3.06 & $14^{\text {th }}$ & Moderate \\
\hline Harassment or Physical/Psychological abuse & 3.43 & 2.64 & 3.04 & $15^{\text {th }}$ & Moderate \\
\hline Resentment & 3.57 & 2.45 & 3.01 & $16^{\text {th }}$ & Moderate \\
\hline
\end{tabular}

*MS = Mean Score; RI = Ranking Index

Further Analysis to understand the dynamism of these negative experience was carried out in this study. This was achieved using principal component analysis (PCA), which showed a three (3) component solution to explain the total variance. In the result's model summary, the Cronbach's Alpha of 0.951 was recorded based on the total Eigenvalue. The 3-dimensions had a variance of $30.9 \%, 14.3 \%$, and $12.4 \%$, making the total variance of $57.6 \%$ explained in the PCA result. Using a midpoint of 0.50 as the cut-off, Table 5 presents the 3-component Analysis of the mentor-mentee relationship's negative experiences. Table 5 showed that the identified negative experiences were reduced from 13 to 16 and classified into three components. The components were titled based on the characteristics and relationships that exist within each element. Table 5 explained that a mentor-mentee relationship's negative experiences could be attributed to Attitude, Emotions, and Motivation. The first component that had a $30.9 \%$ variance was titled the Attitude factor had features such as Bad attitude, Bringing personal problems into the relationship, stealing credit for work done by either party and allowing third-party negative influence, Inappropriate delegation of duties, Sabotage, Resentment, and Unrealistic expectations. These components were due to the attitude of either the Mentor or the mentee, which resulted in the mentor-mentee relationship's negative experience. This means that the attitude factor is a significant component to be checked in a mentor-mentee relationship to forestall negative experiences. The second component, which explained $14.3 \%$ of the total variance, was titled the Emotions factor had features such as Pride, Overdependence, and Too much workload on one party. This study posits 
that for a successful mentor-mentee relationship, wrong emotions should be checked appropriately. Negative emotions in a mentor-mentee relationship will result in feelings of pride, overdependence, and a sense that one is being overworked in the mentor-mentee relationship. The third component, explained by $12.4 \%$ of the total variance, was titled the Motivation factor. It is sad to note that when there is no motivation to be committed to the mentor-mentee relationship, it can lead to loss of interest in the profession by the mentor/mentee, and limited-time would be committed to the relationship.

Considering the factor of poor attitude resulting from the negative experiences in a mentor-mentee relationship, [35] defined attitude as an affective reaction that could either be negative or positive towards a person, thing or activity. [36] opined that attitudes are a strong influence that can alter the quality of a mentor and the mentee's outcome. Their study noted that a poor attitude from the Mentor is a high risk that can ruin a mentor-mentee relationship. [37] stated that this is one reason why negative attitudes towards women in the workplace form a substantial barrier to their careers. It is not only the mentee that is affected. The Mentor is also left dissatisfied. [36] posit that for a successful mentor-assisted relationship, there should be a positive attitude to develop others. The solution is creating a positive attitude in a mentor-assisted relationship is to build friendliness. [38] noted that when someone is friendly, the philosophy of such a person is positive. [39] opined that friendliness can be developed and receive through social interaction between the Mentor and mentee. Through this act, mutual understanding and approachability are formed in the mentor-assisted relationship. Besides, [3] argued that emotional intelligence is vital in managing an effective mentoring relationship. Mentors and mentors should be able to manage/balance their feelings and emotions to not discriminate and take decisive actions within the relationship when the need arises. Mentors need to be selfmotivated to want to develop others. It is a venture that does not bring financial benefit but is rewarding in the long-run.

Table 5. PCA of Negative Experiences in a mentor-mentee relationship

\begin{tabular}{|l|l|c|c|c|}
\hline \multirow{2}{*}{ Component Title } & \multicolumn{1}{|c|}{ Component } & \multicolumn{3}{c|}{ Dimension } \\
\cline { 3 - 5 } & & $\mathbf{1}$ & $\mathbf{2}$ & $\mathbf{3}$ \\
\hline \multirow{5}{*}{ Attitude } & Bad attitude & 0.791 & -0.396 & -0.264 \\
\cline { 2 - 5 } & Bringing personal problems into the relationship & 0.768 & -0.193 & -0.258 \\
\cline { 2 - 5 } & Stealing of credit for work done by either party & 0.710 & -0.415 & -0.278 \\
\cline { 2 - 5 } & Allowing third-party negative influence & 0.709 & 0.273 & 0.158 \\
\cline { 2 - 5 } & Inappropriate delegation of duties & 0.698 & -0.188 & -0.087 \\
\cline { 2 - 5 } & Sabotage & 0.582 & -0.190 & 0.135 \\
\cline { 2 - 5 } & Resentment & 0.580 & 0.100 & -0.627 \\
\cline { 2 - 5 } & Unrealistic expectations & 0.554 & -0.085 & 0.453 \\
\hline Emotions & Pride & 0.383 & 0.650 & -0.103 \\
\hline \multirow{5}{*}{ Motivation } & Overdependence & 0.269 & 0.631 & 0.350 \\
\hline & Too much workload on one party & 0.531 & 0.599 & -0.086 \\
\hline & Loss of interest in profession & 0.352 & -0.315 & 0.699 \\
\cline { 2 - 5 } & Inadequate time for the relationship & 0.198 & -0.415 & 0.617 \\
\hline
\end{tabular}

Variable Principal Normalization. 


\subsection{Potential outcomes to an effective women mentoring program}

This section highlights the benefits accrued to the design sector in the construction industry due to the proper implementation of Women mentoring programs. The potential outcomes can benefit the girl child, the design professional, the design industry, and the economy's growth as a whole. Categorical regression was performed on the dataset of the potential outcomes from the perception of the research participants. Table 6 shows the Model summary of the Analysis, which explained that R2 of $87.6 \%$ contributed to an effective Women mentoring program's potential outcome in the design industry. Furthermore, Table 7 shows that the Analysis of the variance result supported the CAT-REG analysis with an F value of 6.876 and a significance value of 0.000 .

Table 6. Model Summary for CAT-REG on potential outcomes of Women mentoring

\begin{tabular}{|c|c|c|c|}
\hline Multiple R & R Square & Adjusted R Square & Apparent Prediction Error \\
\hline 0.936 & 0.876 & 0.748 & 0.124 \\
\hline
\end{tabular}

Table 8 presents the CAT-REG result for an effective Women mentoring program's potential outcome in the design industry. From Table 8, the potential outcomes which were significant include Improved productivity (Beta factor $=89.3 \%)$, Empowerment of inexperienced personnel (Beta factor $=74.7 \%$ ), Attracting potential female students (Beta factor $=78.4 \%)$, Retaining of women professionals (Beta factor $=72.1 \%$ ), Higher salaries $($ Beta factor $=68.7 \%)$, Higher job satisfaction $($ Beta factor $=40.5 \%$ ) and Increase in role models/mentors (Beta factor $=82.1 \%$ ).

Table 7. ANOVA for CAT-REG on potential outcomes of Women mentoring

\begin{tabular}{|l|c|c|c|c|c|}
\hline & Sum of Squares & df & Mean Square & F & Sig. \\
\hline Regression & 73.558 & 42 & 1.751 & 6.876 & 0.000 \\
\hline Residual & 10.442 & 41 & 0.255 & & \\
\hline Total & 84.000 & 83 & & & \\
\hline
\end{tabular}

This finding is supported by several studies showing immense benefits from the implementation of Women mentoring programs across different sectors of the economy. [40] noted that mentoring relationships are established within many organizations to increase the productivity and performance of the mentee. This has been confirmed in different professions that have used mentorship programs. For instance, mentorship among female graduate nurses, occupational therapy faculty staff, and doctorate students [41]. In [41], it was reported that those who were mentored had a comparative advantage over their not mentored counterparts. As this study has shown, inexperienced personnel are empowered through mentoring programs. Moreover, [42] showed that a successful mentorship program help mentees easily translate the theories they had learned in school to practicable skills, thereby increasing productivity. This shows the similarity between the increase in knowledge and the increase in productivity for the mentee. This is corroborated by [43], in that experience plays a crucial role in increasing productivity. 
Furthermore, [44] and [45] recorded that organizations that have active mentoring programs can attract and advance the career of women, assisting them into leadership and managerial positions. [46] Career advancement is a process whereby employees undergo changes in job performance, job position, promotion, increased earnings, and a better relationship with management in organizations. As the construction industry struggles to retain female workers, [36] noted that a mentor-assisted relationship could keep new female employees. The new employees that are not included in a firm or sector are because they find it difficult to adapt quickly. The construction industry is guilty of this. It is noted to have a harsh working condition and some female workers may not find it conducive. Whereas, a mentor-assisted relationship could help keep the mentee focused and motivated. Mentors can help mentees establish goals and direct and redefine their role when it is not easy to maintain motivation [36].

Table 8. CAT-REG on Potential outcomes to effective Women mentoring

\begin{tabular}{|c|c|c|c|c|c|}
\hline \multirow[b]{2}{*}{ Potential Outcomes } & \multicolumn{2}{|c|}{ Standardized Coefficients } & \multirow[b]{2}{*}{ Df } & \multirow[b]{2}{*}{$\mathbf{F}$} & \multirow[b]{2}{*}{ Sig. } \\
\hline & Beta & $\begin{array}{c}\text { Bootstrap (1000) } \\
\text { Estimate of Std. } \\
\text { Error }\end{array}$ & & & \\
\hline $\begin{array}{l}\text { Improved image of the construction } \\
\text { industry }\end{array}$ & -0.038 & 0.299 & 1 & 0.016 & 0.900 \\
\hline Adequate knowledge transfer & 0.354 & 0.433 & 2 & 0.669 & 0.518 \\
\hline Awareness of construction opportunities & 0.455 & 0.338 & 2 & 1.811 & 0.176 \\
\hline Improved productivity & -0.893 & 0.484 & 2 & 3.413 & 0.043 \\
\hline $\begin{array}{l}\text { Empowerment of inexperienced } \\
\text { personnel }\end{array}$ & 0.747 & 0.287 & 2 & 6.773 & 0.003 \\
\hline Attracting potential female students & -0.784 & 0.354 & 2 & 4.906 & 0.012 \\
\hline Retaining of women professionals & 0.721 & 0.386 & 3 & 3.480 & 0.024 \\
\hline Career progression & -0.704 & 0.471 & 3 & 2.235 & 0.099 \\
\hline Increase in women participation & -0.359 & 0.540 & 2 & 0.442 & 0.645 \\
\hline Improved technical skills among women & 0.570 & 0.504 & 3 & 1.281 & 0.294 \\
\hline Improved guidance and support & 0.340 & 0.424 & 3 & 0.643 & 0.592 \\
\hline Higher salaries & -0.687 & 0.273 & 3 & 6.364 & 0.001 \\
\hline Higher job satisfaction & 0.405 & 0.226 & 2 & 3.227 & 0.050 \\
\hline Positive self-image & 0.231 & 0.497 & 1 & 0.216 & 0.645 \\
\hline Reduced stress & -0.892 & 0.692 & 4 & 1.660 & 0.178 \\
\hline Job security & 0.550 & 0.325 & 2 & 2.864 & 0.069 \\
\hline Less work-family conflict & 0.908 & 0.527 & 2 & 2.964 & 0.063 \\
\hline Increase in role models/mentors & -0.821 & 0.341 & 3 & 5.778 & 0.002 \\
\hline
\end{tabular}

\section{Conclusion and Recommendations}

The study examined the prospects of women mentoring programs in the design sector in the construction industry. Mentees identified the main characteristics that make a good mentor as the ability to teach, listen attentively and communicate effectively. This differed from what mentors perceived to be the characteristics of a good mentee. Mentors identified a good mentee's qualities as one that communicates 
clearly, is focused, and demonstrates intelligence. The study showed that the significant negative experiences in a mentor-mentee relationship include a clash of personalities between the mentors and mentees, stealing credit for work done by both parties, and unrealistic expectations. Furthermore, these negative experiences result from poor attitude, wrong emotions, and loss of motivation. In conclusion, the study showed that proper implementation of Women mentoring programs among design professionals could lead to potential outcomes such as improved productivity, empowerment of inexperienced personnel, attracting likely female students, retaining of women professionals, higher salaries, higher job satisfaction, and an increase in role models/mentors.

The following recommendations are put forward for an effective Women mentormentee relationship between female Architects and Architectural students:

- Personality is an individual self-concept that every mentor/mentee should thrive on understanding. By understanding one's nature, one can learn to effectively manage differences in a mentor-mentee relationship and work effectively with diverse people.

- To forestall negative experiences in a mentor-mentee connection, there is a need for proper training/workshops on Women mentoring for potential mentors and mentees. This would help harness their characteristics, ability to set goals, ensure professionalism, and the ability to give/receive feedback.

- Design firms should strive to incorporate Women mentoring programs to attract and retain female Architectural students and aid career advancement.

- Women mentoring relationships should be continuously monitored and evaluated to identify weaknesses and strengths to prevent negative experiences and build efficient lessons learnt for future Women mentoring programs.

\section{Acknowledgement}

The article processing charge (APC) for this article was supported by Covenant University Centre for Research, Innovation and Discovery, Nigeria.

\section{$7 \quad$ References}

[1] Vainikolo, K. (2017). Women's career paths in the construction industry in New Zealand. Unpublished Masters' Thesis, Auckland University, New Zealand. http://openrepository. aut.ac.nz/bitstream/handle/10292/10995/VainikoloK.pdf?sequence=4\&isAllowed=y

[2] Rogers, R. (2007). From Journeymen to Foremen: Identifying Barriers to, Strategies for, Motivating and Developing First Line Union Supervisors, DePaul University, Chicago, IL.

[3] Nkomo, M. W., \& Thwala, W. D. (2014). Review of the importance of mentoring young graduates in the construction sector in South Africa, in Nkum R.K., Nani G., Atepor, L., Oppong, R.A., Awere E. and Bamfo-Agyei, E. (2014) (Eds.), Proceedings of the 3rd Applied Research Conference in Africa (ARCA) Conference, Accra Ghana, 531-539. https://ujcontent.uj.ac.za/vital/\%20access/manager/Repository?view=list\&f0=sm_creator\% 3A\%22Nkomo\%2C+M.W\%22\&sort=sort_ss_title\%2F 
[4] Afolabi, A., Oyeyipo, O., Ojelabi, R., \& Tunji-Olayeni, P. (2019). Balancing the Female Identity in the Construction Industry. Journal of Construction in Developing Countries, 24 (2), 83 - 104. https://doi.org/10.21315/jcdc2019.24.2.4

[5] Kram, K. (1985). Improving the mentoring process. Training and Development Journal, 44,40 - 43.

[6] Ringen, K., Englund, A., Welch, L., Weeks, J. L., \& Seegal, J. L. (1995). Why construction is different. Occupational Medicine: State of the Art Reviews, 10, 255-259. https://jhu.pure.elsevier.com/en/publications/why-construction-is-different-3

[7] Julia, A. E., \& Donna, E. P. S., (2009). Women Pursuing Careers in Trades and Construction. Journal of Career Development, 36 (1), 68-89. https://doi.org/10.1177/0894 845309340797

[8] Dainty, A., Neale, R., \& Bagilhole, B. (2000). Comparison of Men's and Women's Careers in U.K. Construction Industry. Journal of Professional Issues in Engineering Education and Practice, 126(3), 110- 115. https://doi.org/10.1061/(ASCE)1052-3928(2000)126:3(110)

[9] Amaratunga, R. D. G., Haigh, R. P., Shanmugam, M., Lee, A. J., \& Elvitigalage Dona, N.G. (2006). Construction Industry and Women: A Review of the Barriers. 3rd International SCRI Research Symposium, Delft University, Netherlands. http://usir.sal ford.ac.uk/9877

[10] Fielden, S. L., Davidson, M. J., Gale, A. W., \& Davey, C. L. (2001). Women, equality and construction. Journal of Management Development, 20 (4), 293-304. https://doi.org/10. $\underline{1108 / 02621710110388956}$

[11] Singh, V., \& Vinnicombe, S. (2004). Female FTSE Report. Bedford: Cranfield School of Management. https://www.cranfield.ac.uk/-/media/files/global-centre-for-gender-and-leade rship/the-female-ftse-report-2005.ashx?la=en\&hash=2C8920010349C35CEEEA46D26FC 67FE85419B601

[12] Afolabi, A. O., Tunji-Olayeni, P. F., Oyeyipo, O. O. and Ojelabi, R. A. (2017). The SocioEconomics of Women Inclusion in Green Construction. Construction Economics and Building, 17(1), 70-89. https://doi.org/10.5130/AJCEB.v17i1.5344

[13] Tunji-Olayeni, P. F., Afolabi, A. O., Omuh, I. O., Ojelabi, R. A., Amusan, L. M., \& Ogundipe, K. E. (2017). Attracting and retaining female students in construction related programs. The Turkish Online Journal of Educational Technology, 425 - 430. http://eprints .covenantuniversity.edu.ng/9816/1/Tunji-Olayeni\%20et\%20al.2017.pdf https://doi.org/10. 21125/inted.2016.0432

[14] Sari, R. M., Sumarmi, S., Astina, I. K., Utomo, D. H., \& Ridhwan, R. (2019). Measuring Students Scientific Learning Perception and Critical Thinking Skill Using Paper-Based Testing: School and Gender Differences. International Journal of Emerging Technologies in Learning (iJET), 14 (19), 132 - 149. https://doi.org/10.3991/ijet.v14i19.10968.

[15] Owoseni, A., Ibem, E., \& Opoko, A. (2020). Socio-Economic Profiling of Students and its Impact on Learning Outcomes. International Journal of Emerging Technologies in Learning (iJET), 15 (19), 213 - 222. https://doi.org/10.3991/ijet.v15i19.14649.

[16] Ulfa, S., \& Fatawi, I. (2021). Predicting Factors that Influence Students' Learning Outcomes Using Learning Analytics in Online Learning Environment. International Journal of Emerging Technologies in Learning (iJET), 16 (1), 4 - 17. https://doi.org/10. 3991/ijet.v16i01.16325.

[17] Yokwana, N. R. (2015). Factors contributing to the successful mentorship of women in the South African construction industry. Unpublished Master's Thesis, Cape Peninsula University of Technology, South Africa. http://etd.cput.ac.za/handle/20.500.11838/1064 
[18] Chao, G., Walz, P., \& Gardner, P. (1992). Formal and informal mentor relationships: a comparison on mentoring functions and contrast with non-mentored counterparts. Personnel Psychology, 45, 619 - 636. https://doi.org/10.1111/j.1744-6570.1992.tb00863.x

[19] Underhill, C. M. (2006). The effectiveness of mentoring programs in corporate settings: a meta-analytical review of the literature. Journal of Vocational Behavior, 68, $292-307$. https://doi.org/10.1016/j.jvb.2005.05.003

[20] Donaldson, S. I., Ensher, E. A., \& Grant-Vallone, E. J. (2000). Longitudinal examination of mentoring relationships on organizational commitment and citizenship behavior. Journal of Career Development, 26 (4), 233-249. https://doi.org/10.1177/089484530002600401

[21] Rosa, J. E., Hon, C. K. H., Xia, B., \& Lamari, F. (2017). Challenges, success factors and strategies for women's career development in the Australian construction industry. Construction Economics and Building, 17(3), 27- 46. https://doi.org/10.5130/ajceb.v17 $\underline{\mathrm{i} 3.5520}$

[22] Russell, J. S. (2006). Mentoring in Engineering. Leadership and Management in Engineering, 6 (1), 34 - 37. https://doi.org/10.1061/(ASCE)1532-6748(2006)6:1(34)

[23] Amelink, C. T. (2010). Mentoring and women in engineering (An ARP Literature Overview). Research on women in science and engineering. https://www.engr.psu.edu/ awe/

[24] Hoffmeister, K., Cigularov, K. P., Sampson, J., Rosecrance, J. C., \& Chen, P. Y. (2011). A perspective on effective mentoring in the construction industry. Leadership \& Organization Development Journal, 32(7), 673 - 688. https://doi.org/10.1108/01437731111169997

[25] Hamlin, R. G., \& Sage, L. (2011). Behavioral criteria of perceived mentoring effectiveness: An empirical study of effective and ineffective Mentor and mentee behavior within formal mentoring relationships. Journal of European Industrial Training, 35(8), 752778. https://doi.org/10.1108/03090591111168311

[26] Wong, A. T., \& Premkumar, K (2007). An introduction to mentoring principles, processes and strategies for facilitating mentoring relationships at a distance. http://www.usask.ca/ gmcte/ https://doi.org/10.15766/mep_2374-8265.3148

[27] Stone, P. (2007). Opting out? Why women really quit careers and head home. Journal of Family Communication, 9 (2), 131-133. https://doi.org/10.1080/15267430902776249

[28] Nichols, A. L. (2016). What do people desire in their leaders? The effect of leadership experience on desired leadership traits. Leadership \& Organization Development Journal, 37 (5), 658 - 671. https://doi.org/10.1108/LODJ-09-2014-0182

[29] Blake-Beard, S. D. (2001). Taking a hard look at formal mentoring programs: A consideration of potential challenges facing women. Journal of Management Development, 20 (4), 331 - 345. https://doi.org/10.1108/02621710110388983

[30] Afolabi, A. O., Akinbo, F. T., \& Akinola, A. (2019). Improving Career Development through a Women Mentoring program in the construction industry. Journal of Physics: Conference Series, 1378 (4), 1 - 7. https://iopscience.iop.org/article/10.1088/1742-6596/ 1378/4/042031 https://doi.org/10.1088/1742-6596/1378/4/042031

[31] Matthewson, G. M. (2015). Dimensions of Gender: Women's Careers in the Australian Architecture Profession. Unpublished Thesis submitted to the University of Queensland, Australia. https://espace.library.uq.edu.au/view/UQ:373190/s42738134_phd_submission.p $\underline{\mathrm{df}}$

[32] Fulani, O., Amole, D., Aderonmu, P., Adewale, B., Babalola, D., \& Jegede, F. (2019). Besides Zaha or Adenowo: Investigating the Visibility Status of Female Architects as Role Models for Students of Architecture. International Journal of Innovative Technology and Exploring Engineering, 8 (9), 400 - 407. https://doi.org/10.35940/ijitee.I7493.078919 
[33] Obianuju, E. E., \& Diyenaan, M. D. (2019). Why does Female Underrepresentation Persist in Nigerian Architecture? Civil Engineering and Architecture, 7 (4), 89 - 98. https://doi. org/10.13189/cea.2019.070401

[34] Aigbavboa, C., Oke, A., \& Mutshaen, M. (2016). Challenges of mentoring in South African construction industry. Journal of Economics and Behavioral Studies, 8 (6), 183 187. https://doi.org/10.22610/jebs.v8i6(J).1492

[35] Mitchell, T. R., \& Larson, J. R. (1987). People in organizations: an introduction to organizational behavior, 3rd edition. New York: McGraw-Hill Book Company. https://www.amazon.com/People-Organizations-Introduction-Organizational-Behaviour/d $\mathrm{p} / 0071005854$

[36] Klasen, N., \& Clutterbuck, D. (2002). Implementing mentoring schemes: A practical guide to successful programs. Johannesburg: Butterworth Heinemann. https://www.routledge. com/Implementing-Mentoring-Schemes/Klasen-Clutterbuck/p/book/9780750654302 https: //doi.org/10.4324/9780080508511

[37] Ginige, K. N., Amaratunga, R. D. G., \& Haigh, R. (2007). Improving construction industry image to enhance women representation in the industry workforce. In Boyd, D (Editor): Proceedings 23rd Annual ARCOM Conference. 3-5 September 2007. Belfast, U.K.: Association of Researchers in Construction Management. http://www.arcom.ac.uk/-docs/ proceedings/ar2007-0377-0385_Ginige_Amaratunga_and_Haigh.pdf https://doi.org/10.11 $\underline{08 / 09653560910938510}$

[38] Chapman, E. N. (1999). Your attitude is showing: a prime of human relation, 8th edition. Englewood cliff, J: Prentice Hall. https://www.oreilly.com/library/view/your-attitude-is/0 13022507X/

[39] Vanderbilt, A. A. (2010). Perceptions of career and psychosocial functions between mentor and protégé teachers. Unpublished Thesis submitted to the University of South Florida (USF), Florida. https://scholarcommons.usf.edu/etd/1796/

[40] Kahle-Piasecki, L. (2011). Making a mentoring relationship work: what is required for organizational success. Journal of Applied Business and Economics, 12 (1), 46 - 56. http://www.na-businesspress.com/JABE/kahle-piasecki_abstract.html

[41] Paul, S., Stein, F., Ottenbacher, K., \& Liu, Y. (2002). The role of mentoring on research productivity among occupational therapy faculty. Occupational Therapy International, 9 (1), 24 - 40. https://doi.org/10.1002/oti.154.

[42] Insala. (2012). Mentoring benefits. https://insala.com/mentorin g-benefits.asp

[43] Adam, J. D. (1990). Fundamental stocks of knowledge and productivity growth. Journal of Political Economy, 98 (4), 673-702. https://doi.org/10.1086/261702

[44] Allen,T.D. Eby, L.T. Poteet, M.L. Lentz, E., \& Lima, L. (2004). Career Benefits Associated with Mentoring for Protégés': A Meta-Analysis. Journal of Applied Psychology, 89 (1), 127-136. https://doi.org/10.1037/0021-9010.89.1.127

[45] Giscombe, C. L. (2007). Advancing women through the glass ceiling with formal mentoring. In Ragins, B. R. and. Kram, K. E. (editors). The handbook of mentoring at work: theory, research, and practice. London: Sage Publications. 549-572. https://psy chology.ukzn.ac.za/?mdocs-file=1236 https://doi.org/10.4135/9781412976619.n22

[46] Ackah, C., \& Heaton, N. (2003). Human resource management careers: different paths for men and women? Career Development International, 8 (3), 134-142. https://doi.org/10. $\underline{1108 / 13620430310471041}$ 


\section{Authors}

Adedeji Olushola Afolabi is a faculty at Covenant University in the Department of Building Technology. He holds a $\mathrm{PhD}$ degree from the same university and a Masters' and Bachelors' degree from University of Lagos. He has research interests in Construction Management, Construction IT and Sustainable Construction. He has published in some SCOPUS-indexed international journals and conferences in these areas.

Adedotun Akinola is passionate about international development. He is also a lecturer in the Department of Architecture, Covenant University, Nigeria where He is engaged in teaching and research. He graduated from the Department of Architecture (Bsc, Msc), Covenant University and obtained a professional Master's in Urban Regional Planning (MURP) from the University of Lagos, Nigeria. His research interests are in the areas of Energy Efficient Housing, Pro-poor Housing, Urban Resilience, Urban governance and Environmental justice. He has published in some SCOPUS-indexed international journals

Article submitted 2021-02-12. Resubmitted 2021-03-08. Final acceptance 2021-03-09. Final version published as submitted by the authors. 